\title{
D-8 Ülkelerinde Biyokütle Enerjisi Tüketimi ile Ekonomik Büyüme Arasındaki İlişki*
}

\section{The Relationship Between Biomass Energy Consumption and Economic Growth in D-8 Countries}

\author{
Fatma Fehime Aydın a,** \\ ${ }^{a}$ Dr. Öğr. Üyesi, Van Yüzüncü Y1l Üniversitesi İktisadi ve İdari Bilimler Fakültesi, İktisat Bölümü, 65080, Van/Türkiye. \\ ORCID: 0000-0002-7026-6889
}

\section{MAKALE BILGIISI}

\section{Makale Geçmişi:}

Başvuru tarihi: 02 Ocak 2018

Düzeltme tarihi: 06 Şubat 2018

Kabul tarihi: 19 Şubat 2018

Anahtar Kelimeler:

Biyokütle

Ekonomik Büyüme

Panel Veri Analizi

\section{ARTICLE INFO}

\section{Article history:}

Received 02 January 2018

Received in revised form 06 February 2018

Accepted 19 February 2018

\section{Keywords:}

Biomass

Economic Growth

Panel Data Analyses
ÖZ

Çalışmada, 1980-2013 yılları arasında D-8 ülkeleri (Gelişen Sekiz Ülke) için biyokütle enerji tüketimi ile ekonomik büyüme arasındaki ilişki ele alınmaktadır. Seriler arasında uzun dönem ilişkisi olup olmadığını analiz etmek için panel birim kök, eşbütünleşme ve nedensellik testleri kullanılmaktadır. Bu analizlerin sonucunda değişkenler arasında uzun dönemli bir ilişkinin olduğu görülmektedir. Ardından eşbütünleşik seriler OLS, DOLS ve FMOLS tahmincileri ile tahmin edilmekte ve daha sonra etki-tepki analizi yapılmaktadır. Elde edilen analiz sonuçlarına göre, biyokütle enerji tüketiminden ekonomik büyümeye doğru tek yönlü bir nedensellik ilişkisi ortaya çıkmaktadır. Ayrıca, biyokütle enerji tüketimi ile ekonomik büyüme arasında uzun dönemde pozitif ve istatistiksel olarak anlamlı bir ilişki bulunmaktadır. Bu bağlamda, hükümetlerin biyokütle enerji kullanımına dönük yapılacak yatırım ve projelerinin ekonomik büyümeyi olumlu yönde etkileyeceği görülmektedir.

\section{A B S T R A C T}

In the study, in the period of 1980-2013, the relationship between biomass energy consumption and economic growth in D-8 countries (Developing Eight Countries) is discussed. Panel unit root, cointegration and causality tests are used to analyze whether there is a long-term relationship between the series. As a result of these analyzes, it seems that there is a long-term relationship between the variables. The cointegrated series are then estimated by OLS, DOLS and FMOLS estimators and then impulse-response analysis is performed. According to the obtained analysis results, a one-way causality relationship occurs from biomass energy consumption to economic growth. In addition, there is a long-term positive and statistically significant relationship between biomass energy consumption and economic growth. In this context, it is seen that governments' investment and projects towards biomass energy use will affect economic growth positively.

\section{Giriş}

Günümüzde hemen her alanda kullanılan enerji, insanlar için adeta en temel ihtiyaçlardan biri haline gelmiştir. Artan nüfusla birlikte enerji kullanımı giderek artmakta ve buna bağlı olarak enerji kaynakları sürekli azalmaktadır. Geleneksel fosil yakıtların ya da diğer bir deyişle yenilenemeyen kaynakların tüketilmesi küresel ısınma ve iklim değişikliği gibi önemli sorunlara yol açtığından ve zamanla tamamen tükenmesi söz konusu olacağından ülkeler buna bir alternatif olarak yenilenebilir enerji kaynaklarını kullanmaya yönelmektedirler. Ayrıca bu kaynakların hem miktar hem de çeşitlilik bakımından sınırlı olmasının yansıra, dünyadaki dağılımı da dengeli değildir. Dünyanın kimi bölgeleri miktar ve çeşitlilik açısından diğer bölgelere göre nispi olarak daha fazla rezerve sahiptir ve bu durum da enerjide dışa bağımlılık anlamında ciddi endişeleri gündeme getirmektedir (Aydın ve Esen, 2016).

Yenilenebilir enerji kaynakları; güneş enerjisi, rüzgâr enerjisi, jeotermal enerji, hidrolik enerji, deniz-dalga enerjisi ve biyokütle enerjisi olarak sayılabilir. $\mathrm{Bu}$ enerji kaynaklarından biri olan biyokütle enerjisi, mısır ve buğday gibi bitkilerden, otlardan, yosunlardan, denizdeki alglerden,

\footnotetext{
* Bu çalışma, 25-26 Kasım 2017 tarihlerinde Ankara'da düzenlenen International Conference on Multidisciplinary Sciences adlı konferansta bildiri olarak sunulmuştur.

** Sorumlu yazar/Corresponding author.

e-posta: fehimegul@yahoo.com
} 
hayvan dışkılarından, gübre ve sanayi atıklarından ve evlerden atılan tüm organik çöplerden elde edilen bir enerji türüdür (Yenilenebilir Enerji Genel Müdürlüğü, 2017).

Bu çalışmada 1980-2013 yılları arasında biyokütle enerjisi tüketimi ile GSYİH artışı arasındaki uzun dönem ilişskisi araştırılmıştır. Çalışmada zaman aralığı olarak 1980-2013 döneminin alınmasında biyokütle enerjisi ile ilgili verilerin sınırlı olması belirleyici olmuştur.

Çalışmada biyokütle enerjisi tüketimi ile GSYİH artışı arasındaki uzun dönem ilişkinin incelenmesi amacıyla Gelişmekte Olan Sekiz Ülke (D-8) üzerine çeşitli analizler uygulanmıştır. $\mathrm{Bu}$ ülkeler şöyle sıralanabilir: Bangladeş, Misır, Endonezya, İran, Malezya, Nijerya, Pakistan ve Türkiye. D-8 birliği 15 Haziran 1997 tarihinde İstanbul'da yapılan Devlet/Hükümet Başkanları Zirvesi ile resmen kurulmuştur. D-8, üye ülkeler arasında ekonomik ve ticari işbirliğinin geliştirilmesine yönelik bir oluşumdur. D-8'in kuruluş amac1, gelişmekte olan ülkelerin dünya ekonomisi içindeki konumlarını iyileştirmek, ticari ilişkiler için alternatifler sunmak ve ticaret alanında üye ülkelere yeni imkânlar yaratmak, bu ülkelerin uluslararası seviyede karar verme mekanizmalarına güçlü biçimde katılımlarını sağlamak ve halklarının refah seviyesini yükseltmektir (T.C. Dışişleri Bakanlığı, 2017).

D-8 ülkelerinde, yenilenebilir enerji tüketimi ile ekonomik büyüme arasındaki ilişkiyi inceleyen çalışmalar yapılmıştır. Ancak literatürde biyokütle tüketimi ile ekonomik büyüme arasındaki ilişkiyi inceleyen çalışmalar sınırlı kalmıştır. Bu nedenle çalışmanın bu ülkeleri kapsayacak biçimde yapılmasının literatüre katkı sağlayacağı düşünülmektedir. Global Material Flow veri tabanından elde edilen verilere göre, dünyada 1980-2013 yılları arası toplam biyokütle tüketimi 602.758.853 kiloton iken, çalışmamızda ele aldığımız ülkelerde aynı yıllarda toplam biyokütle tüketimi 59.810.833,45 kiloton kadardır. Dolayısıyla 1980-2013 yılları arasında dünyadaki biyokütle tüketiminin yaklaşık \%10'u ele aldığımız ülkelerde gerçekleşmektedir.

Çalışmada kullanılan veriler biyokütle enerjisi tüketimi, eğitim süresine ve eğitimin getirisine dayalı beşeri sermaye endeksi, sermaye stoku ve harcamalar yönünden reel GSYİH'dır. Çalışmada panel nedensellik, panel birim kök, panel eş bütünleşme analizi, panel en küçük kareler (OLS) yöntemi, homojen ve heterojen dinamik en küçük kareler (DOLS) yöntemleri ile homojen ve heterojen tam modifiye edilmiş en küçük kareler (FMOLS) yöntemleri uygulanmış ve ardından etki tepki analizi yapılmıştır.

Çalışmanın bundan sonraki bölümleri şu şekilde düzenlenmiştir. İkinci bölümde konuyla ilgili önceden yapılan çalışmalara yer verilmiştir. Üçüncü bölümde kullanılan temel model ve veri seti hakkında bilgiler verilmiştir. Dördüncü bölümde çalışmadan elde edilen ampirik bulgular sunulmuştur. Son bölümde ise ulaşılan sonuçlar özetlenmekte ve değerlendirilmektedir.

\section{Literatür Taraması}

Enerji tüketimi ve ekonomik büyüme ilişkisi üzerine farklı yöntemler ve farklı ülkelerin verileri kullanılarak birçok çalışma yapılmıştır. Son yıllarda enerji türlerinden biri olan yenilenebilir enerji kaynakları ile ekonomik büyüme ilişkisi üzerine de çeşitli çalışmalar yapılmaya başlanmıştır (Stern,
2000; Soytas ve Sari, 2003; Altınay ve Karagöl, 2004; Apergis ve Payne, 2010; Herrerias vd., 2013; Aydın ve Esen, 2016; Menegaki ve Tugcu, 2017; Esen ve Bayrak, 2017; Aydin ve Esen, 2017). Ancak yenilenebilir enerji kaynaklarından biri olan biyokütle enerjisi tüketiminin ekonomik büyüme üzerine etkisinin incelendiği çalışmalar ise nispeten sinırlı miktardadır. Tablo 1'de, öncelikle yenilenebilir enerji kaynakları ile ekonomik büyüme ilişkisini ele alan çalışmalara, devamında ise biyokütle enerjisi tüketiminin ekonomik büyümeye etkisini ele alan çalışmalara yer verilmiştir. Biyokütle enerjisi tüketimi ile ekonomik büyüme ilişkisini ele alan ilk çalışma Payne tarafından 2011 yılında yapılmıştır. Bu çalışmanın ardından konu diğer araştırmacılar tarafindan da ilgi odağı olmaya başlamış ve çeşitli çalışmalar yapılmıştır. Yapılan çalışmalarda genel olarak biyokütle enerjisi tüketimi ile ekonomik büyüme arasında pozitif bir ilişki olduğu sonucuna ulaşılmıştır.

\section{Model ve Veri Seti}

Çalışmada D-8 ülkeleri (Bangladeş, Mısır, Endonezya, İran, Malezya, Nijerya, Pakistan ve Türkiye) için ekonomik büyüme ile biyokütle tüketimi arasındaki uzun dönemli ilişkinin incelenmesi amaçlanmıştır. Bu amaçla ele aldığımız temel üretim fonksiyonu aşağıdaki gibidir:

$$
\mathrm{y}_{\mathrm{it}}=\mathrm{F}\left(\mathrm{K}_{\mathrm{it}}, \mathrm{L}_{\mathrm{it}}, \mathrm{N}_{\mathrm{it}}\right)
$$

$\mathrm{Bu}$ fonksiyonda $\mathrm{y}_{\mathrm{it}}=\mathrm{GSYIH}{ }^{\prime} \mathrm{yi} ; \mathrm{K}_{\mathrm{it}}=$ sermaye stokunu; $\mathrm{L}_{\mathrm{it}}=$ işgücünü ve $\mathrm{N}_{\mathrm{it}}=$ doğal kaynakları temsil etmektedir.

(1) nolu üretim fonksiyonundan hareketle bu çalışmada kullanılan değişkenler aşağıdaki gibi sıralanabilir:

(i) Üretim fonksiyonunda bağımlı değişken olarak GSYİH alınmaktadır. Bu çalışmada da bağımlı değişken olarak GSYİH'nin doğal logaritması [satın alma gücü paritesine göre harcamalar yönünden reel GSYİH (2011 baz y1lı, milyon dolar cinsinden)] alınmıştır.

(ii) Üretim fonksiyonunda kullanılan ilk bağımsız değişken sermaye stoku değişkenidir. Bu çalışmada da bu nedenle sermaye stokunun doğal logaritması [cari satın alma gücü paritesine göre sermaye stoku (2011 baz yılı, milyon dolar cincinden)] alınmıştır.

(iii) Üretim fonksiyonunda kullanılan bir diğer değişken işgücü değişkenidir. Burada işgücü değişeni olarak beşeri sermayenin doğal logaritması (eğitim süresine ve eğitimin getirisine dayalı beşeri sermaye endeksi) alınmıştır.

(iv) Üretim fonksiyonunda kullanılan son değişken doğal kaynaklardır. Burada da doğal kaynaklardan biri olan biyokütle tüketiminin doğal logaritması (kullanılan biyokütle ekstraksiyonu) alınmıştır.

Bu değişkenler kullanılarak incelenmek istenen temel model şöyledir:

$$
\begin{aligned}
\operatorname{lnGSYIH}_{\mathrm{it}}=\alpha+ & \beta_{1} \operatorname{lnbiyokütle~}_{\text {it }} \\
& +\beta_{2} \text { lnsermayestoku }_{\mathrm{it}} \\
& +\beta_{3} \operatorname{lnbş̧erisermaye~}_{\mathrm{it}}+\mathrm{e}_{\mathrm{it}}
\end{aligned}
$$

1980-2013 yılları arası biyokütle tüketim verileri Global Material Flow veri tabanından; çalışmada kullanılan diğer veriler ise Penn World Table veri tabanından elde edilmiştir. 
Tablo 1. Yenilenebilir Enerji Tüketimi ile Ekonomik Büyüme Arasındaki ve Biyokütle Tüketimi ile Ekonomik Büyüme Arasındaki İlişkiyi İnceleyen Çalı̧̧malar

\begin{tabular}{|c|c|c|c|}
\hline Yazar & Ülkeler-periyot & Yöntem & Sonuç \\
\hline Sadorsky (2009) & $\begin{array}{l}\text { Gelişmekte olan ekonomiler } \\
(1994-2003)\end{array}$ & Panel eşbütünleşme & $\begin{array}{l}\text { Kişi başına düşen gelirdeki artışlar kişi başına } \\
\text { yenilenebilir enerji tüketimi üzerinde olumlu ve } \\
\text { istatistiksel olarak anlamlı bir etkiye sahiptir. }\end{array}$ \\
\hline Menegaki (2011) & $\begin{array}{l}27 \text { Avrupa ülkesi } \\
(1997-2007)\end{array}$ & Panel-tesadüfi etkiler modeli & $\begin{array}{l}\text { Analiz sonuçlarına göre yenilenebilir enerji tüketimi ve } \\
\text { büyüme arasında nedensellik ilişkisi yoktur. }\end{array}$ \\
\hline Aydın (2013) & G7 Ülkeleri (1991-2009) & $\begin{array}{l}\text { Panel birim kök, panel } \\
\text { eşbütünleşme, nedensellik, etki- } \\
\text { tepki, panel OLS, sabit etkiler } \\
\text { ve tesadüfi etkiler modelleri }\end{array}$ & $\begin{array}{l}\text { Yenilenebilir enerji tüketimi ile ekonomik büyüme } \\
\text { arasında herhangi bir ilişki yoktur. Ancak yenilenebilir } \\
\text { enerji tüketimindeki bir artışın karbondioksit } \\
\text { emisyonunu düşürücü etkisi vardır. }\end{array}$ \\
\hline $\begin{array}{l}\text { Bhattacharya vd. } \\
\text { (2016) }\end{array}$ & $\begin{array}{l}\text { En fazla yenilenebilir enerji } \\
\text { tüketen } 38 \text { ülke }\end{array}$ & $\begin{array}{l}\text { Panel birim kök, panel } \\
\text { eşbütünleşme, OLS, DOLS, } \\
\text { FMOLS, heterojen panel } \\
\text { nedensellik, zaman serisi analizi }\end{array}$ & $\begin{array}{l}\text { Seçilen ülkelerin } \% 57 \text { 'sinde yenilenebilir enerji } \\
\text { tüketiminin ekonomik büyüme üzerinde pozitif ve } \\
\text { anlamlı bir etkisi vardır. }\end{array}$ \\
\hline $\begin{array}{l}\text { Özşahin, Mucuk, } \\
\text { Gerçeker (2016) }\end{array}$ & $\begin{array}{l}\text { BRICS Ülkeleri ve Türkiye } \\
(2000-2013)\end{array}$ & $\begin{array}{l}\text { Panel Cusum Eşbütünleşme, } \\
\text { Panel ARDL }\end{array}$ & $\begin{array}{l}\text { Yenilenebilir enerji tüketimi ve ekonomik büyüme } \\
\text { arasında uzun dönemde, pozitif yönlü bir ilişki olduğunu } \\
\text { göstermektedir. }\end{array}$ \\
\hline Payne (2011) & $\begin{array}{l}\text { ABD } \\
(1949-2007)\end{array}$ & $\begin{array}{l}\text { Toda-Yamamoto nedensellik } \\
\text { testi }\end{array}$ & $\begin{array}{l}\text { Biyokütle enerji tüketiminden ekonomik büyümeye } \\
\text { doğru tek yönlü bir nedensellik ilişkisi mevcuttur ve } \\
\text { büyüme hipotezi geçerlidir. }\end{array}$ \\
\hline Bildirici (2014) & $\begin{array}{l}\text { Geçiş ekonomileri } \\
(1990-2011)\end{array}$ & $\begin{array}{l}\text { Panel ARDL, Pedroni eş } \\
\text { bütünleşme, FMOLS }\end{array}$ & $\begin{array}{l}\text { Biyokütle enerji tüketimi ve ekonomik büyüme } \\
\text { eşbütünleşiktir. FMOLS analizi sonuçlarına göre } \\
\text { biyokütle enerji tüketimi ekonomik büyüme üzerinde } \\
\text { pozitif etkiye sahiptir. }\end{array}$ \\
\hline $\begin{array}{l}\text { Bilgili ve Öztürk } \\
(2015)\end{array}$ & $\begin{array}{l}\text { G7 ülkeleri } \\
(1980-2009)\end{array}$ & $\begin{array}{l}\text { Panel birim kök, panel eş } \\
\text { bütünleşme, OLS ve DOLS }\end{array}$ & $\begin{array}{l}\text { Biyokütle enerjisi tüketimi ekonomik büyüme üzerinde } \\
\text { pozitif etkiye sahiptir. }\end{array}$ \\
\hline $\begin{array}{l}\text { Bildirici ve } \\
\text { Özaksoy (2016) }\end{array}$ & $\begin{array}{l}\text { Sahra altı Afrika ülkeleri } \\
(1980-2013)\end{array}$ & ARDL & $\begin{array}{l}\text { Bazı ülkeler için biyokütle enerjisi tüketiminden } \\
\text { ekonomik büyümeye doğru tek yönlü, bazı ülkeler için } \\
\text { ekonomik büyümeden biyokütle tüketimine doğru tek } \\
\text { yönlü, bazı ülkeler içinse ikisi arasında çift yönlü bir } \\
\text { nedensellik iliş̧kisi vardır }\end{array}$ \\
\hline Bildirici (2016) & $\begin{array}{l}\text { Avustralya, Belçika, } \\
\text { Kanada, Danimarka, } \\
\text { Finlandiya, Fransa, } \\
\text { Japonya, İngiltere, Amerika } \\
(1980-2010) \\
\end{array}$ & ARDL, Granger & $\begin{array}{l}\text { Biyokütle enerjisi tüketimi ve ekonomik büyüme } \\
\text { arasında, tek yönlü bir nedensellik ilişkisi mevcuttur. }\end{array}$ \\
\hline Shahbaz vd. (2016) & $\begin{array}{l}\text { BRICS } \\
(1991-2015)\end{array}$ & $\begin{array}{l}\text { Panel eşbütünleşme, Panel } \\
\text { nedensellik }\end{array}$ & $\begin{array}{l}\text { Biyokütle enerjisi tüketimi ekonomik büyümeyi uyarıc1 } \\
\text { etkiye sahiptir. }\end{array}$ \\
\hline $\begin{array}{l}\text { Aslan } \\
(2016)\end{array}$ & $\begin{array}{l}\text { ABD } \\
(1961-2011)\end{array}$ & ARDL, nedensellik & $\begin{array}{l}\text { Kısa ve uzun dönemde biyokütle enerjisi tüketimi } \\
\text { ekonomik büyüme üzerinde pozitif etkiye sahiptir. } \\
\text { Granger nedensellik sonucuna göre, biyokütle enerjisi } \\
\text { tüketiminden ekonomik büyümeye doğru tek yönlü } \\
\text { nedensellik mevcuttur ve büyüme hipotezi geçerlidir. }\end{array}$ \\
\hline
\end{tabular}

\section{Ampirik Bulgular}

Çalışmada Eviews 9.5 ekonometrik paket programı kullanılmıştır. Panel özellik gösteren veri setinde değişkenler arasında herhangi bir uzun dönemli ilişkiden bahsedebilmek için, ele alınan değişkenlere ait zaman serilerinin durağan özellikler taşıması gerekmektedir. Bu bağlamda, panel veri analizine başlamadan önce serilerin durağan olup olmadıkları ve durağan iseler hangi seviyede durağan oldukları Breitung (2000); Levin, Lin ve Chu (2002); Maddala ve Wu (1999) ve Im, Pesaran, Shin (2003) panel birim kök testleriyle incelenmiştir. Birim kök testlerinin ardından çalışmada değişkenler arasında uzun dönemli bir ilişkinin olup olmadığı Johansen Fisher panel eşbütünleşme testi kullanılarak analiz edilmiştir. Çalışmada ele alınan panel eş-bütünleşme analizi sonuçlarına göre değişkenler arasında uzun dönemli bir ilişkinin olduğunun görülmesiyle, uzun dönem katsayıların tahmininin yapılması gerekmektedir. $\mathrm{Bu}$ bağlamda, eş-bütünleşme vektörünün katsayıları, panel OLS yöntemi, homojen ve heterojen dinamik OLS yöntemleri ile homojen ve heterojen FMOLS yöntemleri uygulanmıştır. Ayrıca değişkenlerin birinde meydana gelen rastgele bir şokun diğer değişkenler üzerindeki etkisini analiz etmek için ise etki tepki analizi yapılmıştır. Çalışmada son olarak değişkenler arasındaki ilişkilerin yönünü belirlemek amacıyla Dumitrescu ve Hurlin (2012) nedensellik testine yer verilmiştir.

\subsection{Panel Birim Kök Testi Sonuçları}

Çalışmada kullanılan panel birim kök testleri Breitung (2000); Levin, Lin ve Chu (2002); Maddala ve Wu (1999) ve Im, Pesaran, Shin (2003)'tür. Bu testlerden Breitung ile Levin, vd.'nin testleri homojen, Maddala ve Wu tarafindan önerilen ADF Fisher ve Im, Pesaran, Shin tarafindan önerilen IPS testi heterojen yapıdadır. 
Tablo 2. Panel Birim Kök Sonuçları

\begin{tabular}{|c|c|c|c|c|}
\hline & $\operatorname{lnGSYİH}$ & lnBiyokütle & lnBeşerisermaye & lnSermayestoku \\
\hline \multicolumn{5}{|c|}{ Düzey için Homojen Testler } \\
\hline Breitung & $0.0067(0.5027)$ & $0.7144(0.7625)$ & $4.2474(1.0000)$ & $1.2497(0.8943)$ \\
\hline Levin vd. & $0.7986(0.7877)$ & $0.7321(0.7680)$ & $-1.5624(0.0591)$ & $-0.9923(0.1605)$ \\
\hline \multicolumn{5}{|c|}{ Heterojen Testler } \\
\hline ADF Fisher & $8.2146(0.9422)$ & $16.6561(0.4082)$ & $21.1146(0.1741)$ & $15.7945(0.4674)$ \\
\hline IPS & $1.3113(0.9051)$ & $1.3223(0.9070)$ & $0.8858(0.8121)$ & $0.2085(0.5826)$ \\
\hline \multicolumn{5}{|c|}{ Birinci Fark için Homojen Testler } \\
\hline Breitung & $-3.8214(0.0001)^{*}$ & $-4.0772(0.0000)^{*}$ & $-0.9679(0.1666)$ & $-0.9461(0.1721)$ \\
\hline Levin vd. & $-2.8981(0.0019) *$ & $-7.8440(0.0000)^{*}$ & $0.13308(0.5529)$ & $-1.6557(0.0489)^{* *}$ \\
\hline \multicolumn{5}{|c|}{ Heterojen Testler } \\
\hline ADF Fisher & $33.7431(0.0059)^{*}$ & $92.1245(0.0000)^{*}$ & $29.6848(0.0197)^{* *}$ & $25.3147(0.0645)^{* * *}$ \\
\hline IPS & $-2.7515(0.0030)^{*}$ & $-8.3642(0.0000)^{*}$ & $-1.7156(0.0431)^{* *}$ & $-1.7345(0.0414)^{* *}$ \\
\hline
\end{tabular}

Çalışmada uygulanan tüm panel birim kök testleri sabit ve trend içermektedir. Parantez içerisindeki değerler olasılık değerleridir. Ele alınan dört değişken için de düzeyde yapılan birim kök test sonuçlarına göre birim kökün sıfır hipotezi reddedilmemektedir. Birinci farklar alındığında ise GSYİH ve biyokütle değişkenleri için dört testin sonucuna göre de sıfır hipotezi reddedilmektedir. Beşeri sermaye değişkeni için Breitung ve Levin, vd. testlerine göre sıfir hipotezi reddedilmemekte ancak ADF Fisher ve IPS testlerine göre sıfir hipotezi reddedilmektedir. Sermaye stoku değişkeni için ise Breitung testi sonucuna göre sıfır hipotezi reddedilmemekteyken, diğer üç testin sonucuna göre de sıfır hipotezi reddedilmektedir. Buna göre ele alınan değişkenlerin birinci farkı alındığında durağan hale geldiği söylenebilir.

\subsection{Panel Eş Bütünleşme Testi Sonuçları}

Çalışmada seriler arasında uzun dönemli karşılıklı bir ilişki olup olmadığının araştırılması amacıyla, 1999 yılında Maddala ve Wu tarafından önerilen Johansen Fisher panel eş bütünleşme analizi uygulanmıştır.

Tablo 3. Panel Eş Bütünleşme Sonuçları

\begin{tabular}{cccc}
\hline Hipotez & İz İstatistiği & Kritik Değer (\%5) & Olasıllk \\
\hline Ho: $r=0$ & 197,8 & 148,6 & 0,0000 \\
Ho: $r \leq 1$ & 77,65 & 47,15 & 0,0001 \\
Ho: $r \leq 2$ & 46,89 & 44,90 & 0,0001 \\
Ho: $r \leq 3$ & 21,41 & 21,41 & 0,1632 \\
\hline
\end{tabular}

Johansen Fisher panel eş bütünleşme testi sonucuna göre, herhangi bir eş bütünleşme olmadığı, en fazla bir eş bütünleşme olduğu ve en fazla iki eş bütünleşme olduğu hipotezleri reddedilmekte, en fazla üç eş bütünleşme olduğu hipotezi ise kabul edilmektedir. Dolayısıyla buradan çıkarılabilecek sonuç şudur ki, ele alınan değişkenler arasında bir eş bütünleşme ilişkisi mevcuttur. Bu bağlamda uzun dönemde ele alınan 8 ülkede ekonomik büyüme, sermaye stoku, beşeri sermaye ve biyokütle tüketimi serileri birlikte hareket etmektedirler.

4.3. OLS, Homojen ve Heterojen Dinamik OLS, Homojen ve Heterojen FMOLS Testlerinin Sonuçları

Bu çalışmada, GSYİH ile biyokütle tüketimi, sermaye stoku ve beşeri sermaye arasındaki ilişkinin katsayılarının tahmini amacıyla beş farklı panel veri analizi uygulanmıştır.
Tablo 4. OLS, DOLS ve FMOLS Testleri Sonuçları

\begin{tabular}{lccccc}
\hline & OLS & $\begin{array}{c}\text { Homojen } \\
\text { DOLS }\end{array}$ & $\begin{array}{c}\text { Heterojen } \\
\text { DOLS }\end{array}$ & $\begin{array}{c}\text { Homojen } \\
\text { FMOLS }\end{array}$ & $\begin{array}{c}\text { Heterojen } \\
\text { FMOLS }\end{array}$ \\
\hline Biyokütle & 0.368 & -1.112 & -1.112 & 0.229 & 0.229 \\
& $(16.961)^{*}$ & $(-2.226)^{*}$ & $(-2.075)^{*}$ & $0.921)^{* *}$ & $(1.134)^{* *}$ \\
\hline Sermaye & 0.616 & 1.137 & 1.137 & 0.850 & 0.850 \\
Stoku & $(27.776) *$ & $(13.567) *$ & $(15.445)^{*}$ & $(18.516)^{*}$ & $(18.580)^{*}$ \\
\hline Beşeri & 0.097 & -0.218 & -0.218 & -0.263 & -0.263 \\
Sermaye & $(0.919)$ & $(-0.233)^{*}$ & $(-0.264)^{*}$ & $(-0.406)^{* *}$ & $(-0.483)^{* *}$ \\
\hline $\mathrm{R}^{2}$ & 0.875 & 0.998 & 0.998 & 0.990 & 0.990 \\
Düzeltilmiş & 0.874 & 0.995 & 0.995 & 0.989 & 0.989 \\
$\mathrm{R}^{2}$ & & & & &
\end{tabular}

$\underline{\mathrm{R}^{2}}$

Not: * \%1, ** \% 5 ve *** \%10 düzeyinde anlamlı olan test değerleridir.

Tablo 4'te gelişmekte olan sekiz ülke için biyokütle, sermaye stoku ve beşeri sermaye açısından GSYİH'nin uzun dönem dinamikleri verilmiştir. Parantez içindeki değerler $t$ istatistikleridir. Tablo incelendiğinde OLS, homojen FMOLS ve heterojen FMOLS modelleriyle yapilan analizlerde panel reel GSYİH'nin doğal logaritmasının panel biyokütle tüketim verisinin doğal logaritmasının artan bir fonksiyonu olduğu sonucu elde edilmiştir. Homojen ve heterojen DOLS modelleriyle yapilan analizlerde ise panel reel GSYİH'nin doğal logaritmasının panel biyokütle tüketim verisinin doğal logaritmasının azalan bir fonksiyonu olduğu sonucuna ulaşılmıştır.

Sermaye stoku için yapılan analizlerden elde edilen sonuçlara göre tüm modellere göre panel reel GSYİH'nin doğal logaritmasının panel sermaye stoku verisinin doğal logaritmasının artan bir fonksiyonu olduğu sonucu elde edilmiştir.

Beşeri sermaye için yapılan analizlerden elde edilen sonuçlara göre OLS modeliyle yapılan analizde panel reel GSYİH'nin doğal logaritmasının panel beşeri sermaye verisinin doğal logaritmasının artan bir fonksiyonu olduğu sonucu elde edilmiştir. Diğer dört model ile yapılan analizlerde ise panel reel GSYİH'nin doğal logaritmasının panel beşeri sermaye verisinin doğal logaritmasının azalan bir fonksiyonu olduğu sonucu elde edilmiştir.

Analizde kullanılan beş modelin R2 ve düzeltilmiş R2 değerlerine bakıldığında, homojen ve heterojen dinamik OLS yöntemleriyle elde edilen tahmin sonuçları tercih edilebilir. Buna göre biyokütle tüketimindeki \%1'lik artış GSYİH'yi \%1.112 azaltacaktır. Sermaye stokundaki \%1'lik artış GSYIH'yi \%1.137 artıracaktır. Beşeri sermayedeki \%1'lik artış ise GSYİH'yi \%0.218 azaltacaktır. 
Şekil 1. Biyokütle Enerji Tüketimi, Ekonomik Büyüme, Beşeri Sermaye ve Sermaye Stoku Arasındaki Etki-Tepki Analizi Sonuçları

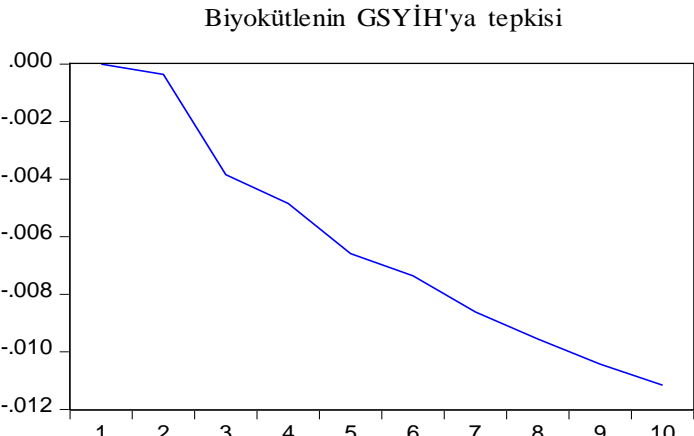

Sermaye stokunun GSYİH'ya tepkisi

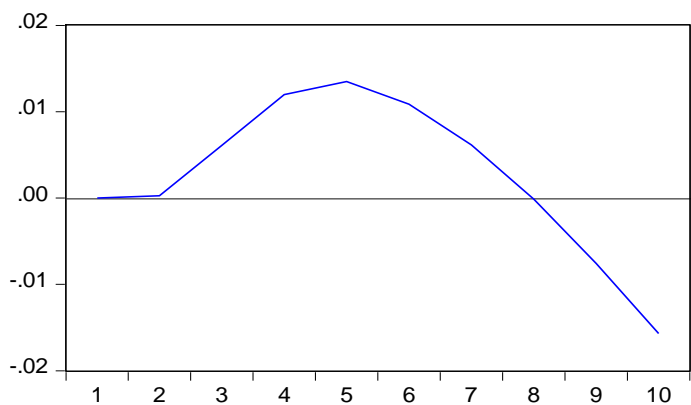

Beşeri sermayenin GSYİH'ya tepkisi

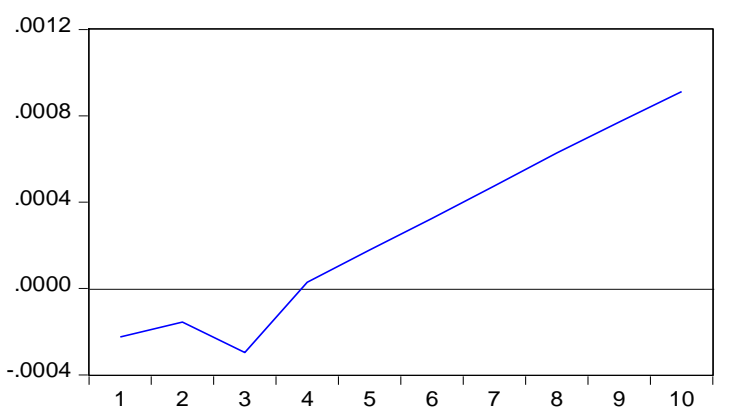

GSYİH'nın biyokütleye tepkisi

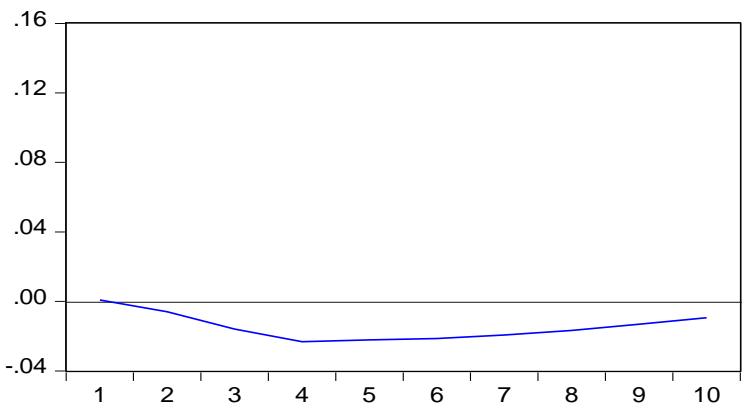

GSYİH'nın sermaye stokuna tepkisi

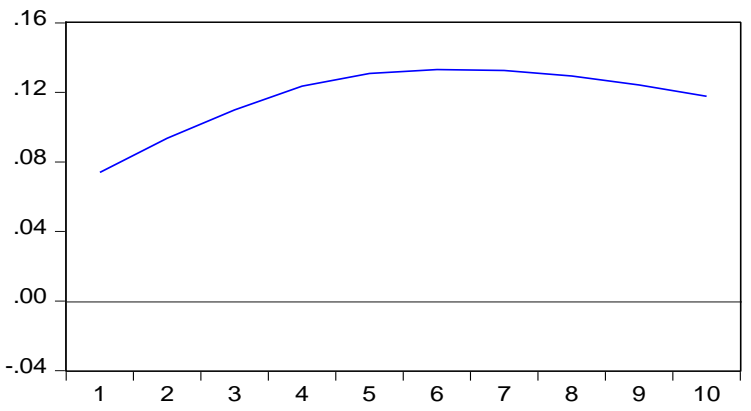

GSYIH'nın beşeri sermayeye tepkisi

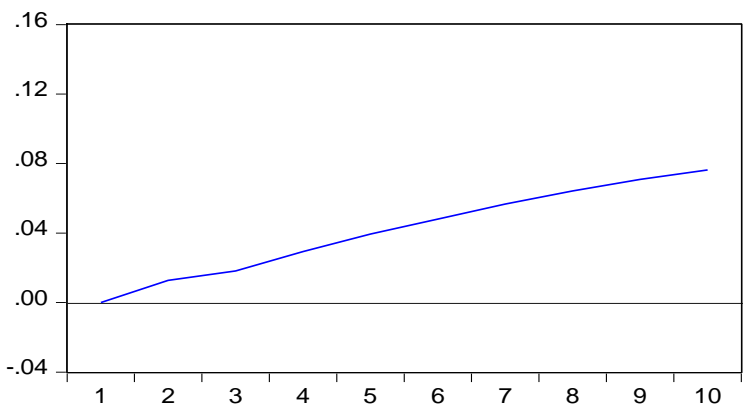

\subsection{Etki-Tepki Analizi Sonuçları}

Etki-tepki analizi, bir değişkende meydana gelen rastgele bir şokun diğer değişkenler üzerindeki etkisini analiz etmekte kullanılır.

Biyokütle enerji tüketimi, ekonomik büyüme, beşeri sermaye ile sermaye stoku arasında meydana gelebilecek beklenmedik artışların birbirleri üzerindeki etkisi, etki-tepki analizi ile araştırılmış ve sonuçlar Şekil 1'de verilmiştir. Şekil 1'deki sonuçlara göre, GSYİH'da meydana gelecek beklenmedik bir şok biyokütle enerji tüketimini aynı dönemde etkileyerek önemli derecede düşürürken sermaye stokunu başlangıçta pozitif yönde etkilerken, 5. dönemden itibaren bu etki negatif bir seyir sergilemiş; beşeri sermaye üzerindeki etkisi ise başlangıçta inişli çıkışlı bir seyir izlerken üçüncü dönemden itibaren pozitif bir seyir izlemiştir. Beşeri sermaye, sermaye stoku ve biyokütle tüketiminde ortaya çıkan ani şokların GSYİH üzerindeki etkileri ise farklı yönlerde olmuştur. Beşeri sermayedeki ani artış GSYİH'nin artmasına neden olmakta ve bu artışın etkisi 10 dönem boyunca sürmekte iken; biyokütle tüketimindeki artış başlangıçta negatif yönde etkilemekte, dördüncü dönemden itibaren pozitif yönde etkilemekte, sermaye stokundaki ani artış ise GSYİH'yi başlangıçta pozitif ancak bir süre sonra negatif yönde etkilemektedir.

\subsection{Panel Nedensellik Testi Sonuçları}

Çalışmada Dumitrescu ve Hurlin tarafından 2012 yılında geliştirilen çift taraflı panel nedensellik testi uygulanmıştır. Gecikme sayısı 2 olarak alınmıştır. Gecikme uzunluğunun belirlenmesinde lag length criteria uygulanmıştır. Test sonuçları aşağıdaki tabloda görülmektedir.

Tablo 5 incelendiğinde üç durum dışında olasılık değerlerinin 0.05 'ten küçük olduğu görülmektedir. Olasılık değerlerinin 0.05 'ten küçük olması sıfır hipotezinin reddedileceği, alternatif hipotezin kabul edileceği anlamına gelmektedir. Buna göre, biyokütle enerjisi tüketimi, beşeri sermaye ve sermaye stoku beklendiği gibi ekonomik büyümenin nedeni olarak çıkmıştır. Ekonomik büyüme ise bu değişkenlerden yalnızca beşeri sermayenin nedeni olarak çıkmıştır. Dolayısıyla biyokütle enerjisi tüketimi ve sermaye stoku değişkenleri ile ekonomik büyüme arasında tek yönlü bir nedensellik varken, beşeri sermaye ve ekonomik büyüme arasında çift yönlü bir nedensellik olduğu söylenebilir. 
Tablo 5. Panel Nedensellik Sonuçları

\begin{tabular}{lccc}
\hline Sıfır Hipotezi & W-İst. & Zbar-İst. Olasılık \\
\hline $\begin{array}{l}\text { GSYİH homojen olarak beşeri } \\
\text { sermayenin nedeni değildir* }\end{array}$ & 5.445 & 3.970 & 0.000 \\
\hline $\begin{array}{l}\text { Beşeri sermaye homojen olarak } \\
\text { GSYİH'nin nedeni değildir* }\end{array}$ & 6.825 & 5.638 & 0.000 \\
\hline $\begin{array}{l}\text { Sermaye stoku homojen olarak beşeri } \\
\text { sermayenin nedeni değildir* }\end{array}$ & 5.16 & 3.635 & 0.000 \\
\hline $\begin{array}{l}\text { Beşeri sermaye homojen olarak sermaye } \\
\text { stokunun nedeni değildir* }\end{array}$ & 7.792 & 6.806 & 0.000 \\
$\begin{array}{l}\text { Biyokütle homojen olarak beşeri } \\
\text { sermayenin nedeni değildir* }\end{array}$ & 7.342 & 6.263 & 0.000 \\
$\begin{array}{l}\text { Beşeri sermaye homojen olarak } \\
\text { biyokütlenin nedeni değildir }\end{array}$ & 3.080 & 1.111 & 0.266 \\
$\begin{array}{l}\text { Sermaye stoku homojen olarak } \\
\text { GSYİH'nin nedeni değildir* }\end{array}$ & 4.838 & 3.237 & 0.001 \\
$\begin{array}{l}\text { GSYİH homojen olarak sermaye } \\
\text { stokunun nedeni değildir. }\end{array}$ & 2.922 & 0.920 & 0.357 \\
\hline $\begin{array}{l}\text { Biyokütle homojen olarak GSYİH'nin } \\
\text { nedeni değildir* }\end{array}$ & 6.552 & 5.308 & 0.000 \\
$\begin{array}{l}\text { GSYİH homojen olarak biyokütlenin } \\
\text { nedeni değildir }\end{array}$ & 3.272 & 1.344 & 0.179 \\
\hline $\begin{array}{l}\text { Biyokütle homojen olarak sermaye } \\
\text { stokunun nedeni değildir* }\end{array}$ & 6.594 & 5.359 & 0.000 \\
\hline $\begin{array}{l}\text { Sermaye stoku homojen olarak } \\
\text { biyokütlenin nedeni değildir* }\end{array}$ & 5.196 & 3.669 & 0.000 \\
\hline
\end{tabular}

\section{Sonuç ve Değerlendirme}

Çalışmanın temel amacı, gelişmekte olan sekiz ülke için biyokütle tüketimi ile GSYİH artışı arasındaki uzun dönemli ilişkiyi dinamik olarak analiz etmektir. Bu amaçla, D-8 ülkelerinin 1980-2013 y1llarına ait biyokütle enerjisi tüketimi, sermaye stoku, beşeri sermaye ve reel GSYİH verilerinin doğal logaritmaları alınarak panel nedensellik, birim kök, eş bütünleşme analizi, panel OLS yöntemi, homojen ve heterojen dinamik OLS yöntemleri ile homojen ve heterojen FMOLS yöntemleri uygulanmış ve ardından, etki tepki analizi yapılmıştır.

Panel OLS, homojen FMOLS ve heterojen FMOLS modelleriyle yapılan analizlerde panel reel GSYİH'nin doğal logaritmasının panel biyokütle tüketim verisinin doğal logaritmasının artan bir fonksiyonu olduğu sonucu elde edilmiştir. Homojen ve heterojen DOLS modelleriyle yapılan analizlerde ise panel reel GSYİH'nin doğal logaritmasının panel biyokütle tüketim verisinin doğal logaritmasının azalan bir fonksiyonu olduğu sonucuna ulaşılmıştır. Analizde kullanılan beş modelin R2 ve düzeltilmiş R2 değerlerine bakıldığında, homojen ve heterojen dinamik OLS yöntemleriyle elde edilen tahmin sonuçlarının tercih edilebilir olduğu sonucuna ulaşılmıştır. Buna göre biyokütle tüketimindeki \%1'lik artış GSYİH'yi \%1.112 azaltacaktır. Sermaye stokundaki \%1'lik artış GSYİH'yi \%1.137 artıracaktır. Beşeri sermayedeki \%1'lik artış ise GSYİH'yi \%0.218 azaltacaktır. Etki tepki analizi sonucuna göre biyokütle tüketimindeki bir birimlik şok başlangıçta GSYİH'yi negatif yönde etkilerken, ilerleyen zamanlarda pozitif yönde etkilemektedir. Panel nedensellik testi sonuçlarına göre biyokütle enerjisi tüketimi, sermaye stoku ve beşeri sermaye ekonomik büyümenin nedenidir. Elde edilen sonuçlar, ele alınan ülkelerde biyokütle tüketiminin ekonomik büyüme üzerinde başlangıçta negatif ancak zamanla pozitif bir etkiye sahip olacağı hipotezini doğrulamaktadır.
Enerji kaynaklarının dünya üzerindeki dengesiz dağılımı, bazı ülkeleri enerji ihracatçısı konumuna getirirken birçok ülkeyi ise enerji konusunda dışa bağımlı hale getirmektedir. $\mathrm{Bu}$ dışa bağımlılık olgusunu ortadan kaldırmanın ya da nispeten azaltmanın yolu ise her yerde rahatlıkla elde edilebilen ve tükenmeyen bir enerji kaynağı olan biyokütle enerjisinin kullanımıdır. Ayrıca petrol, kömür, vb. yenilenemeyen enerji kaynaklarının kullanımı çevreyi de olumsuz yönde etkilemektedir. D-8 ülkelerinde hükümetlerin çevreye zarar vermeksizin ekonomik büyümeyi sağlamak amacıyla yenilenebilir enerji üretimi ve tüketimini artırma yönünde çalışmalar yapması hem küresel 1sınmanın bir sebebi olan karbon emisyonlarının seviyesini azaltacak hem de ekonomik büyümeyi olumlu yönde etkileyecektir. Biyokütle enerjisinin kullanımı yerel üretimi ve istihdamı artırarak da ekonomiyi olumlu yönde etkileyecektir. Biyokütle enerjisinin üretilmesi ve kullanılması tarım ve imalat sektörlerini canlandıracak, bu sektörlerde iş imkânı yaratacak ve bu sektörlerde çalışan kesimin sosyo-ekonomik yapısını iyileştirecektir.

\section{Kaynakça}

Altinay, G., \& Karagol, E. (2004). Structural break, unit root, and the causality between energy consumption and GDP in Turkey. Energy Economics, 26(6), 985-994. http://dx.doi.org/10.1016/j.eneco.2004.07.001

Apergis, N., \& Payne, J. E. (2010). Energy consumption and growth in South America: Evidence from a panel error correction model. Energy Economics, 32(6), 1421-1426. http://dx.doi.org/10.1016/j.eneco.2010.04.006

Aslan, A. (2016). The causal relationship between biomass energy use and economic growth in the United States. Renewable and Sustainable Energy Reviews, 57, 362366.

Aydın, C., \& Esen, O. (2016). Threshold effects of energy consumption on economic growth in Turkey. Journal of Environmental Management and Tourism, 7(3), 370382. http://dx.doi.org/10.14505/jemt.v7.3(15).02

Aydin, C., \& Esen, Ö. (2017). Does Too Much Energy Consumption Harm Economic Growth for Turkish Republics in The Transition Process? New Evidence on Threshold Effects. International Journal of Energy Economics and Policy, 7(2), 34-43.

Aydın, F.F. (2013). $\mathrm{CO}_{2}$ emissions, renewable energy consumption, population density and economic growth in G7 countries. The Journal of Knowledge Economy \& Knowledge Management, VIII(II), 89-104.

Bhattacharya, M., Paramati, S.R., Ozturk, İ., \& Bhattacharya, S. (2016). The Effect of Renewable Energy Consumption on Economic Growth: Evidence from Top 38 Countries. Applied Energy, 162, 733-741.

Bildirici, M. (2014). Relationship between biomass energy and economic growth in transition countries: panel ARDL approach. GCB Bioenergy, 6(6), 717-726.

Bildirici, M. (2016). Biomass energy consumption and economic growth: ARDL analysis, Energy Sources, Part B: Economics, Planning, and Policy, 11 (6), 562-568. 
Bildirici, M., \& Özaksoy, F. (2016). Woody biomass energy consumption and economic growth in Sub-Saharan Africa. Procedia Economics and Finance, 38, 287-293.

Bilgili, F., \& Özturk, İ. (2015). Biomass energy and economic growth nexus in G7 countries: Evidence from dynamic panel data. Renewable and Sustainable Energy Reviews, 49, 132-138.

Breitung, J. (2000). The local power of some unit root tests for panel data. In Nonstationary Panels, Panel Cointegration, and Dynamic Panels. Baltagi B. (ed.). Advances in Econometrics 15 Amsterdam: JAI Press; 161-178.

Diş İşleri Bakanlığı (2018). Gelişen Sekiz Ülke (D-8). (Erişim Tarihi: 10.02.2018), http://www.mfa.gov.tr/ gelisen-sekiz-ulke-_d-8_.tr.mfa

Dumitrescu, E.I., \& Hurlin, C. (2012). Testing for Granger non-causality in heterogeneous panels. Economic Modelling, 29 (4), 1450-1460.

Esen, Ö., \& Bayrak, M. (2017). Does more energy consumption support economic growth in net energyimporting countries?. Journal of Economics, Finance and Administrative Science, 22(42), 75-98. https://doi.org/10.1108/JEFAS-01-2017-0015

Herrerias, M. J., Joyeux, R., \& Girardin, E. (2013). Shortand long-run causality between energy consumption and economic growth: Evidence across regions in China. Applied Energy, 112, 1483-1492.

Im, K. S., Pesaran, M. H., \& Shin, Y. (2003). Testing for unit roots in heterogeneous panels. Journal of econometrics, 115(1), 53-74.

Levin, A., Lin, C. F., \& Chu, C. S. J. (2002). Unit root tests in panel data: asymptotic and finite-sample properties. Journal of econometrics, 108(1), 1-24.

Maddala, G. S., \& Wu, S. (1999). A comparative study of unit root tests with panel data and a new simple test. Oxford Bulletin of Economics and statistics, 61(S1), 631-652

Menegaki, A. N., \& Tugcu, C. T. (2017). Energy consumption and Sustainable Economic Welfare in G7 countries; A comparison with the conventional nexus. Renewable and Sustainable Energy Reviews, 69, 892-901.

Menegaki, A.N. (2011). Growth and renewable energy in Europe: A random effect model with evidence for neutrality hypothesis. Energy Economics, 3(2), 257-263.

Özşahin, Ş., Mucuk, M., \& Gerçeker, M. (2016). Yenilenebilir enerji ve ekonomik büyüme arasındaki ilișki: BRICS-T ülkeleri üzerine Panel ARDL analizi. Siyaset, Ekonomi ve Yönetim Araştırmaları Dergisi, 4 (4), 111-130.

Payne, J.E. (2011). On biomass energy consumption and real output in the US. Energy Sources, Part B: Economics, Planning, and Policy, 6(1), 47-52.

Sadorsky, P. (2009). Renewable energy consumption and income in emerging economies. Energy Policy, 37 (10), 4021-4028.
Shahbaz, M., Rasool, G., Ahmed, K., \& Mahalik, M. K. (2016). Considering the effect of biomass energy consumption on economic growth: Fresh evidence from BRICS region. Renewable and Sustainable Energy Reviews, 60, 1442-1450.

Soytas, U., \& Sari, R. (2003). Energy consumption and GDP: causality relationship in G-7 countries and emerging markets. Energy Economics, 25(1), 33-37. https://doi.org/10.1016/S0140-9883(02)00009-9

Stern, D. I. (2000). Multivariate Cointegration Analysis of the Role of Energy in the US Macroeconomy. Energy Economics, 22(2), 267-283. http://dx.doi.org/10.1016/S0140-9883(99)00028-6

Yenilenebilir Enerji Genel Müdürlüğü (2017). Biyokütle Enerjisi Nedir?. (Erişim Tarihi: 15.02.2017), http://www.eie.gov.tr/yenilenebilir/biyokutle_enerjisi.as $\mathrm{px}$ 